\title{
SUPPLY CHAIN PERFORMANCE IMPROVEMENT STRATEGY THROUGH QUALITY OF SYNERGY IN THE AUTOMOTIVE COMPONENTS INDUSTRY
}

\section{Tri Purwani, Lutfi Nurcholis}

Faculty of Economics, AKI University, Semarang, Indonesia

\section{Info Article}

History Article:

Received September 2015

Approved December 2015

Published March 2016

\section{Keywords:}

Supply Chain Performance;

Synergy;

Standardization;

Transparency

\begin{abstract}
The purpose of this study were 1) develop a new concept of Bilateral Symmetry, which is the ability of similarity based on transparency and standardization, 2) conduct empirical testing and analyzing the effect of bilateral symmetry to the improved supply chain performance through quality of synergy in industrial automotive components. The study population includes the entire automotive component industry in Indonesia. This study used sample of 105 respondents using purposive sampling method to comply with the AMOS program. The study result shows that the ability of similarity standardization and the ability of the similarity of transparency have positive significant impact on the quality of synergy, and quality of synergy have positive significant impact on the supply chain performance. In addition, from the results of hypothesis testing found two strategies that can improve supply chain performance with 1) increasing the ability of similarity standardization and 2) improve transparency through quality of synergy.
\end{abstract}

\section{STRATEGI PENINGKATAN KINERJA RANTAI PASOKAN MELALUI KUALITAS SINERGI PADA INDUSTRI KOMPONEN OTOMOTIF}

\begin{abstract}
Abstrak
Tujuan dari penelitian ini adalah mengembangkan konsep baru bilateral symmetry, yang merupakan kemampuan kesamaan berdasarkan transparansi dan standarisasi, dan melakukan pengujian empiris dan menganalisis pengaruh simetri bilateral untuk peningkatan kinerja rantai pasokan melalui kualitas sinergi pada komponen otomotif industri. Populasi penelitian meliputi seluruh industri komponen otomotif di Indonesia. Penelitian ini menggunakan sampel 105 responden dengan menggunakan metode purposive sampling dan dianalisis dengan program AMOS. Hasil penelitian menunjukkan bahwa kemampuan kesamaan standarisasi dan kemampuan kesamaan transparansi berdampak signifikan positif pada kualitas sinergi, dan kualitas sinergi berdampak signifikan positifterhadap kinerja rantai pasokan. Selain itu, dari hasil pengujian hipotesis menemukan dua strategi yang dapat meningkatkan kinerja supply chain dengan meningkatkan kemampuan kesamaan standarisasi dan meningkatkan transparansi melalui kualitas sinergi.
\end{abstract}

JEL Classification: M3, M31 


\section{INTRODUCTION}

Supply chain management is an important way to enhance the competitive strength. According to Bailey and Rabinovich et al. (2005), the competition is now more focused on integrated supply chain rather than individual companies. According to Rozemeijer and Van Weele (2005), supply chain management is increasingly becoming a major management tasks so that supply chain managers need to be moved to the position of top management to ensure that the allocation of duties, responsibilities and authority of the supply chain is handled at the strategic level.

Along with the growth in automotive sales (4-wheeled vehicles), the manufacturer of spare parts locally predicted trouble chasing market demand surge due to the increase of production capacity conservative. The obstacles include, automotive component industry is still dependent on imported raw materials, such as iron and steel from a number of sources abroad. Local content of cars produced in 2012 are quite large, much larger than the local content of cars in ten years ago. The level of local content in some types of cars has exceeded $70 \%$.

In relation to the automotive industry, the Ministry has three auto industry development policy as follows, developing domestic motor vehicle market through the harmonization of tariffs and taxation policies, increasing the use of domestically produced components in vehicle assembly industry, increasing the use of domestically produced motor vehicles. Main while, problems encountered in meeting local component content among others, high dependence on technology abroad, weak support local research and development institutions, lack of supporting large-scale industry, especially SMEs, supporting technology infrastructure such as certification, laboratories and others do not and dependence in the automotive component procurement overseas.

From the above it can be concluded that the local parts manufacturers predicted trouble chasing market demand surge due to the increase of production capacity constraints conservative and has a dependency on imported raw materials from abroad. Difficulties and constraints can not be separated from the company's supply chain performance, especially in relation to local component suppliers.

\section{Hypothesis Development}

Many studies have examined the effect of similarity on various things such as the quality of relationships, teamwork, strategy, consumer preferences and others. In relation to the quality of the relationship, there are some studies that discuss the similarity as a determinant of the quality of relationships, such as Crosby et al. (1990), Doney and Cannon (1997), Palmatier et al. (2006) and Bergeron and Rajaobelina (2009).

Crosby et al. (1990) and Nyamasege \& Biraori (2015) examined the quality of the relationship between the salesperson and the customer on the life insurance company in the USA. Object of research is 469 heads of household as policy makers aged between 25-44 years. According to Crosby et.al. (1990), there are three types of salesperson similarities are similarity of appearance, lifestyle and status. The similarity of appearance include a characteristic in common, speech and personality. Lifestyle similarities include the similarity of the family situation, interests, political views and values. Similarity status similarities include education level, income level and social class. Crosby et al. (1990) research results found that the three similarities that have a significant effect on the quality of relationships.

Doney and Cannon (1997) examined the quality of industrial relations involving suppliers and buyers in the USA. Their research objects are 678 members of the Association of Purchasing Management. The similarity which is one characteristic of a relationship of trust salespeople bring buyers that salespeople make sharing interests and common values with people in the corporate buyer. Similarity can be a sign to expect the other party to facilitate the goal of one of the parties in a situation of dependence destination. The similarity may encourage the process of intentionality or prediction. Buyers who perceive salespeople have in common can expect the salesperson to hold the common belief about the behavior, objectives and appropriate policies. The buyer expectations increased to trust because buyers feel better in accessing the intention salesperson. Understanding motivation salespeople also easier for buyers to predict the behavior of salespeople who would come by building trust through the prediction process. Research results from Doney and Cannon (1997) found 
that the similarity salesperson significant positive effect on the company's trust buyers.

Research Bergeron and Rajaobelina (2009) examined the antecedents and consequences of the buyer seller relationship quality in the financial services industry. Results of research Bergeron and Rajaobelina (2009) found that the similarity is not significant effect on the quality of relationships. Palmatier et al. (2006) conducted a meta-analysis of the relationship marketing. Results of a meta-analysis Palmatier et al. (2006) states that the relationship between the similarity with the commitment to have the highest reliability, followed by the similarity with trust relationships, relationships similarity with relationship satisfaction and relationship similarity with the quality of the relationship.

\section{Standardization}

Research conducted by Hamel and Prahalad (1994) also emphasize increased interdependence between markets. To be an effective global competitor, the company should facilitate cross-subsidies. One way to facilitate cross-subsidy is the standardization of products and global marketing strategy.

According Samiee and Roth (1992), standardization can be interpreted as a similarity marketing strategies applied in the market. According Cateora and Graham (1999), the failure to respond could hinder the company's success in the international market. The company's existing network operations worldwide internally be incompatible with the standardization strategy. According Cateora and Graham (1999), marketers must be careful and sensitive to cultural differences the state for survival and security in the international market. Standardization approach feasible only if the culture does not differ significantly.

According Cavusgil and Zou (1993), standardization can be interpreted as a domestic marketing strategy that was applied to the foreign market. Meanwhile, according to Zou and Cavusgil (1996), externally standardization strategy is subject to government regulations and differences in marketing infrastructure. According Zou and Cavusgil and Zou (1993) and, standardization strategy can not be done when government regulations create a different market, especially when the foreign business is required to meet the environmental regulations, product safety standards or local content requirements.

According to Zou and Cavusgil (1996), competitor strategy also limits the feasibility of standardization in the approach to international markets. According Cavusgil and Zou (1993), Yip (1989) and Arifianti (2013) if the practice to win the competition is the adaptation program and marketing processes on the foreign market, the company's approach to standardization could be reduced. According Cavusgil and Zou (1993), global product standardization involving the development of products of high quality and low costs require little or no customization for sale in foreign markets.

Standard procedure has a style as follows; demonstrate how to do the best activities, the easiest and safe; provides knowledge management methods through know-how and expertise; can be used as reference for performance evaluation, provides basic maintenance and repair activities, provides basic training, audit and diagnosis. The use of standard procurement procedures can reduce the likelihood of misidentification causes problems buying process. If the problem has been identified, the corrective action can be quickly implemented and procedures can be rewritten to eliminate the problem (Anand \& Kodali, 2010).

According to Jayaram and Vickery (1998), the effect on the performance of the purchase of material standardization does not exist. research of Jayaram and Vickery (1998) analyzed the procurement lead time relationship with performance empirically and identified standardization as antecedents performance of lead-time procurement. Jayaram and Vickery (1998) defines standardization as use of procedures, materials, components and standardized processes to design and make products. But research Jayaram and Vickery (1998) does not consider the use of a standard procedure of purchase.

Jayaram et al. (2000) using standardized definitions Jayaram and Vickery (1998) and examine the effect of information systems infrastructure and process improvement strategies empirically on several time-based performance indicators. Jayaram et al. (2000) found that the standardization of the most influential on the speed of delivery and responsiveness to customer performance. Standardization of procedures, 


\section{Tri Purwani \& Lutfi Nurcholis/ Supluy Chain Performance Improvement...}

components and processes can contribute to the timely delivery and effectiveness of fulfilling the needs of customers, which in turn a positive effect on business performance. Jayaram et al. (2000) also did not consider the use of standard purchasing procedure and did not examine the effect of standardization on the performance of purchase.

Standardization of materials, components and purchasing procedures have been considered by the practitioners and academic as purchasing and business performance improvement. Arguments supporting this relationship is based on contradictory evidence, case studies and empirical studies with limited sample (Porter, 1985; Jayaram and Vickery, 1998; Jayaram et al., 2000; Muafi \& Nilmawati, 2014), therefore it is still necessary empirical evidence that access comprehensive benefits related to the standardization of materials and procedures of purchase and its impact on business performance and purchase.

According to Davenport et al. (2004), the main purpose of standardization of business processes, information and practices of information management is to control and minimize the variability of the business units spread in various organizations and achieve greater efficiency and consistency in implementation. Organization might be difficult to achieve the basic control of their own business without practices and standard management information processes. Integration with the supply chain process control and information management practices are inadequate really can make the organization has the weakest connection in the network. Standardized processes and information that are enabled by the implementation of the ERP system/ Enterprise Resource Planning can play an important role in integrating and managing the supply chain.

Seethamraju (2008) developed a number of attributes that are different but interlinked where the standardization process characterized found that the opposite seems to be two models, namely cooperation and competition form the industry standard way that may arise. Standard model selection can be based partnership, in which the standards are chosen through negotiations. In this case, the company voluntarily submit their products to a consortium or default settings. According Wegberg (2004), a stan- dard will then be selected and made accessible to the public in exchange for a certain license fee for all those involved. A model of competition based on the other hand shows that the standard chosen by mediation market activities mostly involve a number of companies who only bring their products that are not compatible to the market where they will fight each other for dominance.

Efforts to standardize the standards can be done singly or together. The difference between the two models comes down to the level of cooperation that use standard setter. Two types of cooperation are called here. The first concerns the collaborative relationships between various standard setters themselves. In this type, a variety of companies from the same industry choose to coordinate the standardization process rather than fighting in the market. The second type refers to the partnership that sets the standard setter with third party companies, such as manufacturers of complementary products, vendors and technology partners. According to Shapiro and Varian (1999), while the standardization process is purely based competition, engineering and promotion of standards generally will be individual businesses that are mostly done by large companies that affect and cheap.

\section{Transparency}

Florini (1998) defines transparency as opposed to secrecy, while the International Monetary Fund (1999) describe as an environmental transparency in the organization that affect the internal and external processes. Transparency provide results that are useful to build relationships and trust. In addition, transparency could be seen as a relational condition or a variable that promotes accountability, collaboration, cooperation and commitment. Organizational decision-making and operational processes which will impact on the transparent accountability. Internal and external stakeholders can also view the location of responsibility. In addition, organizational transparency can also increase trust and accountability through increased collaboration and cooperation (Jahansoozi, 2006).

Visibility of supply chain information is the number of demand and supply information for the planning and management of control possessed by 
supply chain partners. According to Lee (1997), the information flow between customers and suppliers can balance supply and demand by reducing uncertainty and bullwhip effect throughout the network. According to Dyer (1997), the exchange of information on forecasting, planning, product design and production scheduling reduce the asymmetry of information and monitoring costs, reducing incentives for opportunistic behavior transactors. According Mabert and Venkataramanan (1998), increased visibility combined with other resources in an enterprise not only improve decision-making ability of individual companies, but also the basis for improving supply chain performance.

According to Kulp et al. (2004), the demand for real-time data and visibility of supply is critical to the effectiveness of forecasting, planning, scheduling and supply chain execution. Visibility through organizational boundaries can improve the efficiency of the supply chain, helping to reduce cycle time and inventory shortages. Some researchers have studied full transparency as a manifestation of trust organization. Williamson (2005), which held 10 in-depth interviews with investors and managers of public relations, followed by separate interviews with 66 middle-level managers in five organizations with different geographical locations stated that given the openness of the external is to direct research to relatively little to the predictive ability or the consequences of transparency and even less research into the effects of the organizational structure and functions on the establishment of confidence in the broader social context.

Research Williamson (2005) aims to examine the transparency and confidence in the relationship between investors and public relations manager. Transparency and trust have an important role in communication with the stakeholders of the organization. According to Williamson (2005), the important role of transparency is intended to understand how the transfer of trust in the social context of the organization for the benefit of the organization and stakeholders. Transfer the same as the relay, in which the key relationships within the organization initially focus on building trust in the Dyad and extend trust to a third party. Williamson (2005) further stated that transparency is a factor responsiveness and organizational success.
According to Quint Studer (CEO of Studer Group), transparency has 8 the following benefits: (1) can plan and act to adjust, (2) connect and push for action and change, (3) to help see the forces that affect the bottom line, (4) enables a consistent message and avoid distortion of news through gossip, (5) creates consistency and motivated to respond in a similar way. Companies that consistently tend to be healthy and stable, because of the transparency and consistency are the two sides of the same coin, (6) causes the execution quickly, efficiently, facilitating alignment and create a sense of urgency, and (7) to heal our divisions or those working on goals different, (8) makes high-performing people still want to work at a company that treats them with respect.

\section{Synergy}

Ansoff (1988) looked at synergy as one of the main components of the product market strategy of the company. This is related to the suitability of the desired characteristics between the company and the market entry of new products the company. Ansoff (1988) view show that synergy is basically a match between the units. Most studies have used the concept of synergy. The synergy is important in the initial decision to diversify and suggested another way to understand the synergy. There are four types of synergies based formula ROI components, namely sales synergies, operational, investment and management. Therefore, the expected synergies with the synergies that can be achieved is very different and can be negative.

Literature and economic strategy defines the concept of synergy in terms of super-additive value or sub-additive cost (Tanriverdi and Venkatraman 2005). Two business units (a) and (b) enjoy superadditive value synergies if they join value greater than the sum of their individual values: values $(a, b)>$ value (a) + value (b). They enjoy sub-additive cost synergies (or economies of scope) if the use of the common factor of production reduces the cost of production joint business units: cost $(a, b)<\operatorname{cost}(a)+\operatorname{cost}(b)$.

The linkage of resources and resource complementarity are the two main sources of cross-unit multi-business synergy within the company (Tanriverdi, 2005; Tanriverdi \& Venkatraman, 2005). Resource relatedness refers to the use of common resources 


\section{Tri Purwani \& Lutfi Nurcholis/ Supluy Chain Performance Improvement...}

(ie, the common factor of production) in all business units. According to RBV diversification, the use of a common factor in the production of all multi-business unit creates a sub-additive production costs synergies (Farjoun, 1998; Robin \& Wiersema, 1995).

Resource complementarity is also a major source of cross-unit synergies (Tanriverdi \& Venkatraman, 2005). According to the economic theory of complementarities (Milgrom \& Roberts, 1990), the circuit is a complementary resource when the resource returns in the rate of return on other resources. At the time of separate resources, they are also interdependent. They jointly mutually supportive and reinforcing. Join complementary resources value greater than the sum of their individual values (Barua \& Whinston, 1998). So resource complementarity creates a synergy super additive value.

Rumelt (1974) found differences in patterns of diversification in the company and suggested certain categories and classifications to describe the differences company. He is also examine the correlation between diversification and synergies (between companies) on the economic performance of companies. Rumelt (1974) research results establishes three results of synergy, namely operational synergies (based on technical and / or market interdependence), managerial synergy (based on managerial talent and engineering) and financial synergies.

Results of financial synergies are to enhance the ability, to obtain external funding and the capacity to use internal capital for the most promising business divisions. Most companies are trying to achieve financial synergies at levels lower managerial synergy. Many companies that have a diversified business that is not related to the business owned. Corporations (conglomerates) is characterized to have a high degree of decentralization (Rumelt, 1974).

Based on the literature review above, it can be said that the similarity is an important factor in establishing a relationship because of the absence of similarity will result in the emergence of conflict in the relationship. The concept of bilateral symmetry is a relationship based on shared transparency and standardization, which has the potential to improve the quality of synergy transparency and standardization are the two important things that is a unity that must be considered in shaping the quality of synergy as seen in Figure 1. If the relationship does not exist in common synergies transparency there will be an asymmetry of information that impact on the integration process in the relationship that can lead to an imbalance of the process and the bullwhip effect can harm other members. If the relationship does not exist in common synergies standardization then the buyer will be moved to other suppliers who have the same standards to the buyer. Based on these descriptions, it can be hypothesized:

H1: ability of standardization similarity have positive and significant impact on the quality of synergy.

$\mathrm{H} 2$ : the ability of the transparency similarity have positive and significant impact on the quality of synergy.

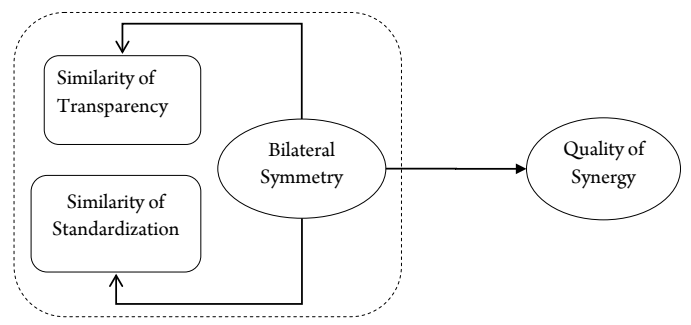

Figure 1. Concept of Billateral Symmetry

\section{Supply Chain Performance}

A framework for supply chain management by using the theory of strategic management to identify key indicators of collaborative inter-company profit to measure performance. The overall performance framework includes the Balanced Score Card, performance matrices, determinants and outcomes framework, time-based competition and the use of the framework of inputs, processes, outputs and outcomes. Therefore, performance measures should be financial and non-financial (Neely et al., 1999; Chen \& Paulraj, 2004; Thatte et al., 2013; Azwar et al., 2014).

Folan and Browne (2005) expand research Neely et al. (1999) for a review of more recent research on the performance matrix and further divide the framework for structural or procedural. According Folan and Browne (2005), most of the performance measurement system from industry and attempts to determine the best practices into a framework of performance. Sharma et al. (2005), which examines a case study of performance measurement using four small and medium enterprises in India, found that the 
use of information technology to facilitate the implementation of a performance measurement system for daily operations.

According Lancioni et al. (2000), Mentzer et al. (2001) and Balasubramanian et al. (2002), the integration of the supply chain offers several benefits which include minimizing bullwhip effect, minimize inventory in the supply chain, reduce cycle time and achieve a greater degree of flexibility. According to the three researchers, supply chain approach will lead to a common problem of excessive lead time, less availability, less reliability and responsiveness. Gunasekaran et al. (2001) presents a list of financial measures and non-financial, which are grouped based on the level of strategic, tactical and operational, while Rungtusanatham et.al. (2003) presents a concept of strategic management performance by utilizing the concept of the resource-based view of the firm to develop insights into the relationship between the company and measure operational performance.

Sharma et.al. (2005) who investigated the small and medium enterprises (SMEs) in research regional company in India. Although these companies acknowledge the need for global performance indicators, their focus on day-to-day performance. The problems are a major concern is the quality, cost, timeliness, performance and capacity utilization. Each of these problems can be converted to fee-based performance measurement. This study is further enhanced by Sanchez and Bhagwat (2006), which examines the role of information systems in adopting measures of performance of SMEs. Cigolini et al. (2004) and Stock et al. (2010) summarize the literature most of the supply chain into a conceptual model to streamline transactions. This model is further classified into three categories relating to information, coordination and control. Chan and Qi (2003) propose a processbased approach to support the model of supply chain performance.

Folan and Browne (2005) presents a performance measurement system extended enterprise by combining internal, suppliers, customers and extend the company's perspective combined with a balanced scorecard framework as the performance of the supply chain that is able to measure the performance of inter-organizational tested in a case study. Finley and Srikanth (2005) focus on the success of supply chain collaboration and found that connectivity knowing inventories relative to the supply chain and demand forecasts are required.

According to Hines et al. (2004) and Handfield et al. (2015), the size of the supply chain is used to establish a comparison between periods, the same organization activity and competition among organizations. The size of the supply chain typically involves measuring the efficiency that include on-time delivery, order completeness, time used, the production lead time/ time to market and reach financial measurements that include asset utilization, capacity, inventory and inventory turnover, profitability and ROI. Based on these descriptions, it can be hypothesized:

H3: quality of synergy have positive and significant impact on the performance of the supply chain.

\section{METHOD}

The concept of research shows in Figure 2. The study population was the entire automotive component industry in Indonesia (GAIKINDO, AISI and GIAMM Data). To determine the amount of the sample by reference to a slovin formula, obtained a minimum of 65 samples. This study used 105 respondents as sample. The sampling technique was conducted using purposive sampling with criteria: 1) the age of the company less than 5 years. 2) The company must have the quality standar departement. Sampling was conducted in Bekasi, Karawang and Semarang. This research uses a quantitative approach that is explanatory research through survey methods, namely by means disseminating the questionnaire respondents. Meanwhile, the data analysis instrument used is Structural Equation Modeling (SEM) in AMOS 21.0.

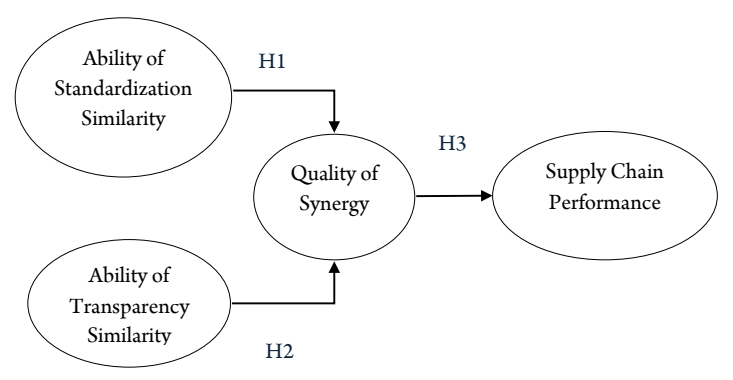

Figure 2. Research Model 
Tri Purwani \& Lutfi Nurcholis/ Supluy Chain Performance Improvement...

\section{RESULT AND DISCUSSION}

\section{Results Analysis}

Results of data processing with AMOS program is presented as shown in Figure 3. Through a full analysis of the model will look whether there is a fitness model and causality built in models tested. Assumptions Evaluation of Data Normality. Normality analysis done by observing the value of CR Multivariate the range $\pm 2: 58$ on the level of significance of $1 \%$. Normality test data is presented through the analysis of AMOS, as presented in Table 1.

Normality test results are presented in Table 1 shows that the value of $\mathrm{CR}$ for univariate no $>2: 58$ so it can be said that in univariate normal distribution of data. As for the multivariate value is 4511 which is above 2:58, so it can be said that the data distribution is not normal multivariate. However, according to $\mathrm{Kli}$ ne (2011) states that the condition of normal distribution in multivariate data can be received when the univariate normal distribution of data.

\section{Multivariate Outliers}

Using the distribution Table 2, to calculate the Mahalanobis Distance is based on the value of Chi-Square at 12 degrees of freedom (the number of observed variables) at the level of $\mathrm{p}<0.001$ was $\mathrm{c} 2$ $(12,0001)=32$ 909. The expected value p1 small, but small value $\mathrm{p} 2$ column shows the observation that much of the value centroid and is considered an outlier and must be dropped from the analysis. AMOS computing Mahalanobis distance produce the maximum number is $25,431<32,909$ so it can be concluded that there are no multivariate outliers.

\section{Assumptions evaluation Multicolinearity and Singularity}

Based on the output data of the sample moment in Table 3 obtained information that the data kovaransi sample matrix is positive definite. This is demonstrated by the Determinant of sample covariance matrix $=25461.407$ much greater than zero. It shows in the data sample is not contained multicollinearity problem. There is a tendency that the data multicolinearity cases can also be seen from the statistical condition number $(\mathrm{cn})$ kovaransi matrix or correlation matrix. If $\mathrm{cn}>1000$ contained multicollinearity problems, lack of it, in the sample data does not indicate there is a problem multicollinearity (Gujarati, 2010). It can be ascertained with the value (cn) of 14293 is not contained in the data multicolinearity cases.

\section{Evaluation of Residual Value Assumptions}

Test the residual value can be done by taking into account the value of the standardized residuals. The expected value of the standardized residuals ge-

Tabel 1. Assessment of Normality (Full Model)

\begin{tabular}{lrrrrrr}
\hline Variable & min & $\mathbf{m a x}$ & skew & c.r. & kurtosis & c.r. \\
\hline KNJ1 & 4.000 & 10.000 & -.140 & -.584 & -.970 & -2.029 \\
KNJ2 & 4.000 & 10.000 & -.068 & -.286 & -.943 & -1.972 \\
KNJ3 & 4.000 & 10.000 & -.096 & -.403 & -1.050 & -2.196 \\
SNG1 & 2.000 & 10.000 & -.117 & -.489 & -.622 & -1.301 \\
SNG2 & 2.000 & 9.000 & -.402 & -1.681 & -.440 & -.920 \\
SNG3 & 3.000 & 10.000 & -.223 & -.934 & -.615 & -1.285 \\
TRP1 & 2.000 & 10.000 & -.188 & -.787 & -.761 & -1.591 \\
TRP2 & 3.000 & 10.000 & -.409 & -1.712 & -.537 & -1.123 \\
TRP3 & 3.000 & 10.000 & -.446 & -1.866 & -.684 & -1.430 \\
STD1 & 2.000 & 10.000 & -.254 & -1.061 & -.306 & -.641 \\
STD2 & 3.000 & 10.000 & -.194 & -.813 & -.506 & -1.059 \\
STD3 & 2.000 & 10.000 & .082 & .345 & -.720 & -1.505 \\
\hline Multivariate & & & & & 4.511 & 1.261 \\
\hline
\end{tabular}


Jurnal Dinamika Manajemen, 7 (1) 2016, 32-44

Table 2. Observations farthest from the centroid

\begin{tabular}{rrrr}
\hline \multicolumn{1}{c}{ Observation number } & Mahalanobis d-squared & \multicolumn{1}{l}{ p1 } & \multicolumn{1}{l}{ p2 } \\
\hline 37 & 25.431 & .013 & .744 \\
97 & 25.424 & .013 & .395 \\
8 & 25.274 & .014 & .172 \\
100 & 24.438 & .018 & .117 \\
95 & 23.176 & .026 & .143 \\
101 & 21.768 & .040 & .248 \\
$\ldots \ldots$ & $\ldots \ldots$ & $\ldots \ldots$ & $\ldots \ldots$ \\
24 & 4.889 & .962 & .783 \\
\hline
\end{tabular}

Tabel 3. Sample Covariances (Full Model)

\begin{tabular}{|c|c|c|c|c|c|c|c|c|c|c|c|c|}
\hline & KNJ1 & KNJ2 & KNJ3 & SNG1 & SNG2 & SNG3 & TRP1 & TRP2 & TRP3 & STD1 & STD2 & STD3 \\
\hline KNJ1 & 2.840 & & & & & & & & & & & \\
\hline KNJ2 & 1.446 & 2.970 & & & & & & & & & & \\
\hline KNJ3 & 1.460 & 1.013 & 2.819 & & & & & & & & & \\
\hline SNG1 & .585 & .726 & .715 & 2.799 & & & & & & & & \\
\hline SNG2 & .573 & .454 & .886 & 1.066 & 2.421 & & & & & & & \\
\hline SNG3 & .805 & .558 & .854 & 1.729 & 1.634 & 2.980 & & & & & & \\
\hline TRP1 & -.413 & -.461 & .161 & .650 & .160 & .663 & 3.618 & & & & & \\
\hline TRP2 & -.072 & -.250 & .672 & .722 & .625 & .752 & 1.192 & 3.112 & & & & \\
\hline TRP3 & .217 & .133 & .767 & .809 & .670 & 1.113 & 1.459 & 1.413 & 3.772 & & & \\
\hline STD1 & -.087 & .247 & .130 & .492 & .377 & .777 & .890 & .777 & .546 & 3.469 & & \\
\hline STD2 & .069 & .261 & 609 & .525 & .848 & 1.102 & .551 & .472 & .757 & .749 & 2.628 & \\
\hline STD3 & .051 & .742 & .416 & .796 & .641 & 1.193 & .931 & .480 & .538 & 1.457 & 1.750 & 4.133 \\
\hline
\end{tabular}

Condition number $=14.293$

Eigenvalues

11.0175 .9994 .5162 .9652 .5642 .3102 .0151 .7801 .2691 .2281 .128 .771

Determinant of sample covariance matrix $=25461.407$

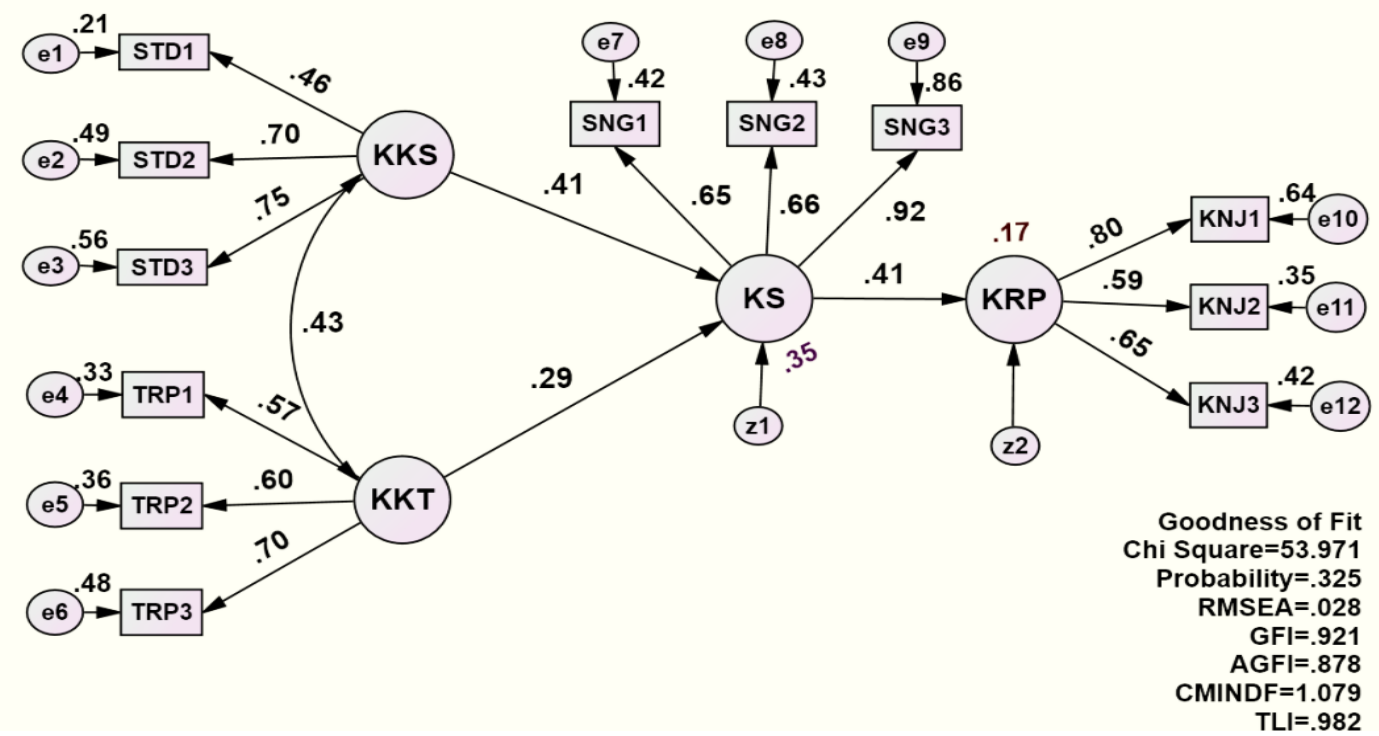

Figure 3. Analysis Model Full Structural Equation Modeling 
Tri Purwani \& Lutfi Nurcholis/ Supluy Chain Performance Improvement...

Table 4. Standardized Residual covariances (Full Model - Default model)

\begin{tabular}{|c|c|c|c|c|c|c|c|c|c|c|c|c|}
\hline & KNJ1 & KNJ2 & KNJ3 & SNG1 & SNG2 & SNG3 & TRP1 & TRP2 & TRP3 & STD1 & STD2 & STD3 \\
\hline KNJ1 & .000 & & & & & & & & & & & \\
\hline KNJ2 & .187 & .000 & & & & & & & & & & \\
\hline KNJ3 & -.025 & -327 & .000 & & & & & & & & & \\
\hline SNG1 & -.045 & .951 & .842 & .000 & & & & & & & & \\
\hline SNG2 & .033 & .097 & 1.665 & -155 & .000 & & & & & & & \\
\hline SNG3 & -.251 & -.367 & .506 & -.004 & .002 & .000 & & & & & & \\
\hline TRP1 & -2.191 & -2.087 & - 200 & .324 & -1.211 & -.432 & .000 & & & & & \\
\hline TRP2 & -1.175 & -1.524 & 1.560 & .639 & .442 & - -109 & .114 & .000 & & & & \\
\hline TRP3 & -400 & -.392 & 1.525 & .398 & .094 & .327 & -.023 & -.050 & .000 & & & \\
\hline STD1 & -1.097 & .180 & -.233 & -009 & -312 & .150 & 1.414 & 1.206 & .154 & .000 & & \\
\hline STD2 & -.984 & .026 & 1.270 & -.488 & .889 & .458 & .081 & -.144 & .328 & -.715 & .000 & \\
\hline STD3 & -1.167 & 1.169 & .172 & -238 & -.585 & -272 & .594 & -.573 & -.843 & .410 & .068 & .000 \\
\hline
\end{tabular}

Table 5. Test Results Full Feasibility Model Structural Equation Modeling

\begin{tabular}{lccc}
\hline \multicolumn{1}{c}{ Goodness of Fit Index } & Cut off Value & Model Result & Model evaluation \\
\hline Chi-Square (df=28) & $<56.892$ & 53.971 & Good \\
Probability & $\geq 0,05$ & 0.325 & Good \\
RMSEA & $\leq 0,08$ & 0.028 & Good \\
GFI & $\geq 0,90$ & 0.921 & Good \\
AGFI & $\geq 0,90$ & 0.878 & Marginal \\
CMIN/DF & $\leq 2,00$ & 1.079 & Good \\
TLI & $\geq 0,95$ & 0.982 & Good \\
CFI & $\geq 0,95$ & 0.986 & Good \\
\hline
\end{tabular}

nerated $<2: 58$. From the results of statistical analyzes conducted in this study are presented in Table 4, there are no standardized residual value of covariance is more than 2:58 so that it can be said that the residual requirement has been met. So it can be concluded that the data used in this study has been accepted significant because residual values $<2.58$.

\section{Conformance Test Model-Goodness of Fit Test.}

Test the feasibility of SEM full model was tested in the same way to test confirmatory factor analysis by using the value Chi ᄀ Square, RMSEA, GFI, AGFI, CMIN / DF, TLI and CFI as presented in Table 5. Results of testing the feasibility of a full model analysis of structural equation modeling showed that the model meets the criteria for goodness of fit has been determined. From the discussion, the third hypothesis proved positive and significant impact. Therefore, it can be said that the ability of similarity standardization positive and significant impact on the quality of synergies, the ability of the similarity of transparency positive and significant impact on the synergies and quality synergies positive and significant impact on the performance of the supply chain.

Results of this research has also produced two scenarios strategies to improve supply chain performance automotive industry and automotive components in Indonesia, firstly, a strategy to improve supply chain performance automotive industry and automotive components in Indonesia through improving the quality of synergy that is done by increasing the ability of the similarity of standardization in supply chain relationships. Second, strategies to improve supply chain performance automotive and automotive component industry in Indonesia through improving the quality of synergy that is done by increasing the ability of the similarity of transparency in the supply chain relationships. Those scenarios is predicted to improve the performance of supply chain automotive industry and automotive components. 


\section{CONCLUSIONAND RECOMMENDATION}

From the discussion, all of the hypothesis proved positive and significant impact. Therefore, it can be said that the ability of similarity standardization positive and significant impact on the quality of synergies, the ability of the similarity of transparency positive and significant impact on the synergies and quality synergies positive and significant impact on the performance of the supply chain. Based on the hypothesis test results, can be prepared strategy to improve supply chain performance automotive and automotive component industry in Indonesia through improving the quality of synergy that is done by increasing the ability of the similarity of standardization in the supply chain relationships.

\section{REFERENCES}

Anand, G \& Kodali, R. 2010. Development of a Framework for Implementation of Lean Manufacturing Systems. International. Journal of Management Practice, 4(1): 95-116.

Ansoff, H. I. 1988. The New Corporate Strategy. New York: Wiley

Arifianti, R. 2013. Analisis Kualitas Produk Sepatu Tomkins. Jurnal Dinamika Manajemen. 4(1): 46-58.

Bailey, J. P \& Rabinovich, E. 2005. Internet Book Retailing and Supply Chain Management: An Analytical Study of Inventory Location Speculation nd Postponement. Transportation Research-Part E: Logistics and ransportation Review. 41(3): 159-77.

Balasubramanian, S., Peterson, R. A \& Jarvenpaa, S. 2002. Exploring the Implications of M-Commerce for Markets and Marketing. Journal of the Academy of Marketing Science. 30(4): 348361.

Barua, A \& Whinston, A. B. 1998. Decision Support for Managing Organizational Design Dynamics. Decision Support Systems. 22(1): 1008-1024.

Bergeron J. and Rajaobelina L. 2009. Antecedents and Consequences of Buyer-Seller Relationship Quality in the Financial Services Industry. International Journal of Bank Marketing. 27(5): 359-380.

Cateora, P. R \& Graham, J. L. 1999. International
Marketing. 10th edition. Boston: Irwin McGraw-Hill.

Cavusgil, S. T \& Zou, S. 1993. Product and Promotion Adaptation in Export Ventures: An Empirical Investigation. Journal of International Business Studies. 24: 479-506.

Chan, F. T. S \& Qi, H. J. 2003. An Innovative Performance Measurement Method For Supply Chain Management. Supply Chain Management-An International Journal. 8(3): 209-223.

Cigolini, R., Cozzi, M \& Perona, M. 2004. A New Framework for Supply Chain Management: Conceptual Model and Empirical Test. International Journal of Operations and Production Management. 24(1): 7-14.

Chen, I. J. \& Paulraj, A. 2004. Towards a Theory of Supply Chain Management-The Constructs and Measurement. Journal of Operations Management. 22(2): 119-150.

Crosby, L. A., Evans, K.R \& Cowles, D. 1990. Relationship Quality in Services Selling: An Interpersonal Influence Perspective. Journal of Marketing. 54(3): 68-81.

Davenport, T. H., Harris, J. G \& Cantrell, S. 2004. Enterprise Systems and Ongoing Process Change. Business Process Management Journal. 10: 16-26.

Doney, P. M \& Cannon, J. P. 1997. An examination of the nature of trust in buyer-seller relationships. Journal of Marketing. 61(2): 35-51.

Dyer, J. H. 1997. Effective Interfirm Collaboration: How Firms Minimize Transaction Costs and Maximize Transaction Value. Strategic Management Journal. 18: 535-556.

Farjoun, M. 1998. The Independent and Joint Effects of the Skill and Physical Bases of Relatedness in Diversification. Strategic Management Journal. 19(7): 611-630.

Florini, A. 1998. The end of Secrecy. Foreign Policy. 111: 50-63.

Finley, F \& Srikanth, S. 2005. 7 Imperatives for Successful Collaboration. Supply Chain Management Review. 9: 30-37.

Folan, P \& Browne, J. 2005. A Review of Performance Measurement: Towards Performance Management". Computers in Industry. 56: 663-680.

Gujarati, D. 2010. Ekonometrika Dasar. Salemba Empat, Jakarta.

Gunasekaran, A., Patel, C \& Tirtiroglu, E. 2001. Performance Measures and Metrices in a Supply Chain Environment. International Journal 
Tri Purwani \& Lutfi Nurcholis/ Supluy Chain Performance Improvement...

of Operations and Production Management. 21(1/2): 71-87.

Hamel, G \& Prahalad, C. K. 1994. Competing for the Future. Boston, MA: Harvard Business School Press.

Handfield, R. B., Cousins, P. D., Lawson, B \& Petersen, K. J. 2015. How Can Supply Management Really Improve Performance? A KnowledgeBased Model of Alignment Capabilities. Journal of Supply Chain Management. 51(3): 3-17.

Hines, P., Holweg, M \& Rich, N. 2004. Learning to Evolve - A Review of Contemporary Lean Thinking. International Journal of Operations and Production Management. 24(10): 994-1011.

Jayaram, J \& Vickery, S. K. 1998. Supply-Based Strategies, Human Resource Initiatives, Procurement Leadtime, and Firm Performance. International Journal of Purchasing and Materials, 34(1): 12-24.

Jayaram, J., Vickery, S. K \& Droge, C. 2000. The Effects of Information System Infrastructure and Process Improvements on Supply-Chain Time Performance. International Journal of Physical Distribution and Logistics Management. 30(3/4): 314-30.

Jahansoozi, J. 2006. Organization-Stakeholder Relationships: Exploring Trust and Transparency. Journal of Management Development. 25(10): 942-955.

Kline, RB. 2011. Principles and practice of structural equation modeling ( $3 r d$ ed.). New York: The Guilford Press.

Kulp, S. C., Lee, H. L., and Ofek, E. 2004. "Manufacturer Benefits from Information Integration with Retail Customers," Management Science (50:4), April, pp. 431-444

Lancioni, R., Smith, M. F \& Oliva, T. A. 2000. The Role of the Internet in Supply Chain Management. Industrial Marketing Management. 29: $45-56$

Lee, H. L \& Tang, C. S. 1997. Modelling the Costs and Benefits of Delayed Product Differentiation. Management Science. 43(1): 40-53.

Mabert, V. A \& M. A. Venkataraman. 1998. Special Research Focus on Supply Chain Linkages: Challenges for Design and Management in the 21st Century. Decision Sciences. 29(3): 537-553.

Mentzer, J. T., DeWitt, W., Keebler, J. S., Min, S., Nix, N. W., Smith, C. D \& Zacharia, Z.
G. 2001. Defining Supply Chain Management, Journal of Business Logistics. 22(2): $1-25$.

Milgrom, P \& Roberts, J. 1990. Bargaining Costs, Influence Costs, and the Organization of Economic Activity in J.E. Alt and K.A. Shepsle (eds.). Perspectives on Positive Political Economy, Cambridge: University of Cambridge. 57-89.

Muafi, M., \& Nilmawati, N. 2014. Budaya Mutu dan Implementasi ISO 2008: 9001 serta Dampaknya terhadap Komitmen Organisasional. Jurnal Dinamika Manajemen. 5(1): 33-47.

Neely, A., Gregory, M \& Platts, K. 1999. Performance Measurement System Design: A Literature Review and Research Agenda. International Journal of Operations and Production Management. 15(4): 80-116.

Nyamasege, O.J \& Biraori, O. E. 2015. Effect of Supplier Relationship Management on the Effectiveness of Supply Chain Management in the Kenya Publicsector. International Journal of Managing Value and Supply Chains. 6(1): 25-32

Robin J \& Wiersema MF. 1995. A Resource-Based Approach to The Multibusiness Firm: Empirical Analysis of Portofolio Interrelationships and Corporate Financial Performance. Management Journal. 16: 277-299.

Palmatier, R. W., Dant, R. P., Grewal, D \& Evans K. R. 2006. Factors Influencing the Effectiveness of Relationship Marketing: A Meta-Analysis. Journal of Marketing. 70: 136-153.

Porter, M. E. \& Millar V. E. 1985. How Information Gives You Competitive Advantage. Harvard Business Review. 63 (4): 149-152.

Rozemeijer, F. A \& Van Weele, A. J. 2005. Making the Most of Corporate Purchasing: Understanding Organizational Behaviour, in Calvi, R. and Merminod, N., Researches in purchasing and supply management, Proceedings. Presented at the 14th IPSERA Conference, Archamps, France, 893-903.

Rumelt, R. P. 1974. Strategy, Structure and Economic Performance. Cambridge: Division of Research Harvard University

Rungtusanatham, M., Salvador, F., Forza, C \& Choi, T. Y. 2003. Supply-Chain Linkages and Operational Performance: A Resource-BasedView perspective. International Journal of $O p$ erations and Production Management. 23(9): 
1084-1099.

Samiee, S \& Roth, K. 1992. The influence of Global Marketing Standardization on Performance. Journal of Marketing. 56: 1-17.

Sanchez, R \& Bhagwat, R. 2006. Practice of Information Systems: Evidence from Select Indian SMEs. Journal of Manufacturing Technology Management. 17(2): 199-223.

Seethamraju, Ravi. 2008. Role of Enterprise Systems In Achieving Supply Chain Integration International Journal of Business Insights and Transformation. 1(1): 18-25

Shapiro \& Varian. 1999. Information Rules: A Strategic Guide to the Network Economy. Boston: Harvard Business Press.

Sharma, M. K., Bhagwat, R \& Dangayach, G. S. 2005. Practice of Performance Measurement: Experience from Indian SMEs. International Journal of Globalization and Small Business. 1(2). 183-213.

Stock, J. R., Boyer, S. L \& Harmon, T. 2010. Research Opportunities in Supply Chain Management. Journal of the Academy of Marketing Science. 38(1): 32-41
Tanriverdi, H \& Venkatraman, N. 2005. Knowledge Relatedness and Performance of Multibusiness Firms. Strategic Management Journal. 26(2): 97-119

Tanriverdi, H. 2005. Information Technology Relatedness, Knowledge Management Capability and Performance of Multibusiness Firms. MIS Quarterly. 29(2): 331-334

Thatte, A. A., Rao, S. S \& Ragu-Nathan, T. S. 2013. Impact of SCM Practices of A Firm On Supply Chain Responsiveness And Competitive Advantage Of A Firm. The Journal of Applied Business Research. 29(2): 499-530.

Wegberg. 2004. Standardization Process of Systems Technologies: Creating a Balance between Competition and Cooperation. Technology Analysis and Strategic Management. 16(4): 457-478.

Williamson, O. E. 2005. Transaction Cost Economics and Business Administration. Scandinavian Journal of Management. 21(1). 19-40.

Zou, S \& Cavusgil, T. 1996. Global Strategy: A Review and An Integrated Conceptual Framework. European Journal of Marketing. 30(1): 52-69. 